\title{
Quality indicators: tools for the management of best practices in Health
}

\author{
Indicadores de qualidade: ferramentas para o gerenciamento de boas práticas em saúde \\ Indicadores de calidad: herramientas para la gestión de buenas prácticas en salud
}

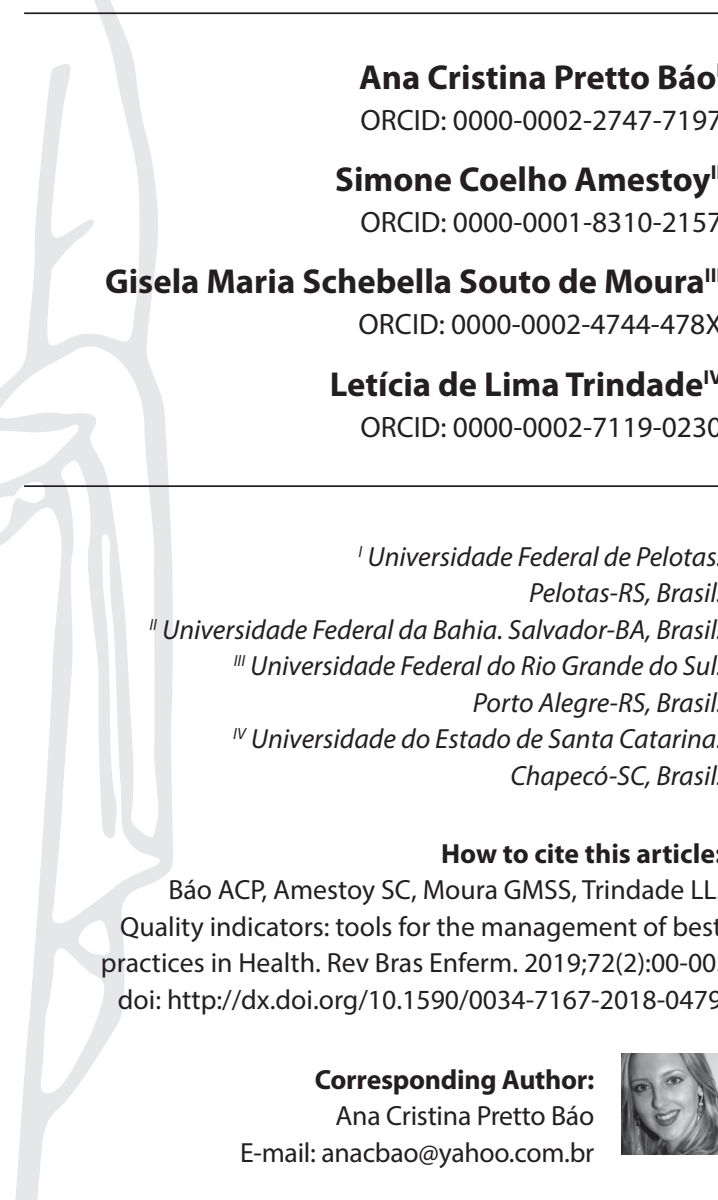

Submission: 06-16-2018

Approved: 08-19-2018

\section{ABSTRACT}

Objective: To analyze how nurses recognize and use quality indicators, aimed at contributing to the management of best practices in Health. Method: Case study with a qualitative approach, conducted with twelve nurses from a hospital in southern Brazil from March to May 2016. For data collection, semi-structured interviews and focus groups were used. Data were subjected to content analysis, in the thematic modality. Results: The data showed that quality indicators are regarded as a tool for measuring health care outcomes, promoting the improvement of continuous care, assisting in the clinical decision-making and being present in discussions with the nursing team, in addition to contributing to the management of best practices in Health. Final Consideration: Quality indicator may support improvements in health services and in the nursing work, strengthening health policies.

Descriptors: Quality Indicators, Health Care; Quality of Health Care; Nursing Assessment; Leadership; Nursing.

\section{RESUMO}

Objetivo: Analisar como os enfermeiros reconhecem e utilizam os indicadores de qualidade, com vistas a contribuir para o gerenciamento de boas práticas em saúde. Método: Estudo de caso com abordagem qualitativa, realizado com doze enfermeiras de um hospital no Sul do Brasil no período de março a maio de 2016. Para a coleta dos dados, foram utilizadas entrevistas semiestruturadas e grupo focal. Os dados foram submetidos a análise de conteúdo na modalidade temática. Resultados: Os dados mostraram que os indicadores de qualidade são reconhecidos como ferramenta de mensuração do resultado assistencial, promovem a melhoria contínua da assistência, auxiliam na tomada de decisão clínica e estão presentes nas discussões com a equipe de enfermagem, assim como contribuem com o gerenciamento de boas práticas em saúde. Considerações Finais: Os indicadores de qualidade podem subsidiar melhorias nos serviços de saúde e no trabalho da enfermagem e fortalecer as políticas de saúde. Descritores: Indicadores de Qualidade em Assistência à Saúde; Qualidade da Assistência à Saúde; Avaliação em Enfermagem; Liderança; Enfermagem.

\section{RESUMEN}

Objetivo: Analizar cómo los enfermeros reconocen y utilizan los indicadores de calidad, con el objetivo de colaborar con la gestión de buenas prácticas en salud. Método: Estudio de caso de tipo cualitativo, del cual participaron doce enfermeras de un hospital de la región Sur de Brasil, en el período de marzo a mayo de 2016. En la recolección de los datos, se utilizaron entrevistas semiestructuradas y grupo de enfoque. Se sometieron los datos a análisis de contenido en la modalidad temática. Resultados: Los datos revelaron que se reconocen los indicadores de calidad como una herramienta de medición del resultado asistencial, pues promueven una mejora continua de la asistencia, auxilian en la toma de decisión clínica y están presentes en las discusiones del personal de enfermería, así como contribuyen a la gestión de buenas prácticas en salud. Consideraciones Finales: Los indicadores de calidad pueden ofrecer avances en los servicios de salud y el trabajo de enfermería, además de fortalecer las políticas de salud.

Descriptores: Indicadores de Calidad de la Atención de Salud; Calidad de la Atención de Salud; Evaluación en Enfermería; Liderazgo; Enfermería. 


\section{INTRODUCTION}

Health services assessment is required as part of the routine in health work, allowing the identification of weaknesses and opportunities for improvement. In this perspective, care actions of the nursing team must be monitored, aimed at knowing their results and establish the best evidence-based practices.

Quality indicators can be a means to measure and evaluate nursing actions. Management tools that guide the path to care excellence consist of the manner through which health professionals verify an activity, monitor aspects related to a given reality, and asses what is happening to patients, pointing to the efficiency and effectiveness of the process and to organizational results ${ }^{(1-2)}$.

On the international scenario, the use of indicators to measure hospital performance became a standard practice in recent years $^{(3-5)}$. A study conducted in the Netherlands, for example, verified the statistical association between the process of injury prevention by pressure and the occurrence of skin lesion, showing that its prevalence is related to the quality of care; therefore, the monitoring of this process indicator may provide information for future changes ${ }^{(3)}$.

Nationally, studies ${ }^{(2,6-7)}$ on care assessment indicate that nurses value the use of quality indicators to evaluate the nursing work performance; hence, these tools must be managerial instruments for health professionals, aiming at improving the care provided. They also indicate the care assessment through indicators is very important for the management of best practices in nursing, providing subsidies for the decision-making related to the quality and safety in the services.

Thus, the nurse contributes with the results, from the best actions adopted in health care and guided by the evidence-based practice. In the clinical setting, this professional plays the role of a reference to the team and is responsible for reducing risks and damages, incorporating best practices in Health, and use quality indicators through a registration system, to favor the effectiveness and management of care and the change in the organizational culture $^{(8)}$, aligned with the Unified Health System (SUS) policies. Yet, when it comes to the nursing staff coordinator, they should encourage its members in care action planning, aimed at promoting excellence in the management of quality of the care provided ${ }^{(9)}$.

Narrowing the focus of this discussion to the hospital environment, the National Policy of Hospital Care (PNHOSP), established in 2013, sets out the guidelines for organizing the hospital component in the health care network $(\mathrm{HCN})^{(10)}$ within the SUS, serving as a subsidy to the best practices of Health in the institutions.

The hospital management must be coordinated with strategies for monitoring and assessing the commitments and targets agreed upon in the government contracts; in addition, the quality of actions and services must be systematically evaluated, in conjunction with the SUS managing bodies, subsidizing the process of planning and managing care by the results of the evaluation of indicators ${ }^{(10)}$. As such, hospitals can use indicators to assist in strengthening the PNHOSP, striving for a care based on best practices.

In nursing, best practices of care may have an impact on the control of injuries and in the qualification of the care provided and should be supported by scientific evidence and assumptions that guide the health care and the SUS. This involves encouraging the critical attitude of nurses before their work processes in the $\mathrm{HCN}$, based on evidence-based practice, understood as the conscious and explicit application of the current best evidence in the decision-making process that is inherent to the individual care ${ }^{(11)}$.

Given these considerations, we believe the results of this research may offer subsidies for the reflection on how quality indicators have been recognized and used by nursing professionals, aimed at strengthening the SUS guidelines and principles, as well as the evidence-based practice.

\section{OBJECTIVE}

To analyze how nurses recognize and use quality indicators in the health care practice, aimed at contributing to the management of best practices in Health.

\section{METHOD}

\section{Ethical aspects}

The study development was in accordance with Resolution $466 / 2012$ of the National Health Council on research with human beings and was approved by the Research and Ethics Committee (CEP).

\section{Type of study}

The research has a qualitative approach, in which the case study was adopted as a research strategy. This is a multiple case study, aimed at analyzing how nurses recognize and use quality indicators in the health care practice, with the purpose of contributing to the management of best practices in Health.

\section{Methodological procedures}

\section{Study scenario}

This study was carried out in a teaching hospital of philanthropic, non-profit nature, which serves more than $60 \%$ of its patients through SUS. The establishment has 293 beds and belongs to the northeastern region of the State of Rio Grande do Sul, being a reference in urgency, emergency, and high complexity to about 1 million people. Qualified as level II by the National Accreditation Organization (ONA), the institution has a quality management model - the quality indicators, a tool that presents a historical line of records from an electronic information system, are used for almost ten years.

In its setting, the institution has seven care units open, providing care to clinical and surgical patients. Nurses who work in this area can participate in the study group on the institution's quality indicators, which takes place once a month and consists of 22 professionals, aiming at analyzing the health care results.

\section{Data source}

The study population comprises nurses from open care units and amounts to 29 professionals. The sample was intentional, through the convenience method. As inclusion criteria, were considered those who worked in the institution for at least one 
year and partaking in the study group on quality indicators. Professionals away due to vacation, maternity leave, and sickness were excluded. Thus, twelve professional agreed to participate in the research and signed the Informed Consent Form (ICF).

\section{Data collection and organization}

Data collection took place from March to May 2016, through the semi-structured interview and focus group techniques. On average, interviews lasted for 30 minutes and were held in a room that ensured privacy, within the very hospital. There were twelve interviews, and the data collection was suspended when one of the researchers realized the data saturation. The interview script consisted of seven questions addressing the topic of quality indicators: "What do you understand as quality indicators?," "What do you consider a good management of best practices in Health?," "How do quality indicators are used?," "What are the contributions provided by the use of quality indicators in the management of best practices in Health?", "Are there difficulties in the use of indicators?," "Does the knowledge on indicators assist in the work process for the management of best practices in Health?," and "Which strategies for using quality indicators do contribute with the management of best practices in Health?."

After the semi-structured interviews ended, the data collection through focus group technique started. The twelve nurses were invited to participate in two meetings, which aimed at presenting data from the interviews for validating them with the participants, in addition to verifying the emergence of new insights on the topic. In this step, seven nurses participated, giving uniformity to the group. Meetings were held in a secluded place within the institution and lasted for one hour, with the presence of the group coordinator - in this case, the lead researcher, previously trained to work with this data collection technique - and an observer, a Nursing Ph.D. student.

To better record interviews and discussions in the focus group meetings, they were record in audio, with consent from the participants, and transcribed in full. At the end of each meeting, the coordinator and the observed gathered to discuss what happened at the meeting.

To ensure anonymity, statements from each participant were encoded by the letter $\mathrm{N}$ (nurse) and the ordinal number corresponding to the sequence in which the interviews were conducted; data from the focus groups were encoded as FG plus the ordinal number representing each nurse (FG1, FG2...).

As a criterion for data organization, the Consolidated Criteria for Reporting Qualitative Research (Coreq) was used.

\section{Data analysis}

Data were subjected to content analysis, in the thematic modality ${ }^{(12)}$. Initially, the exploratory phase of the research was carried out. Then, the interpretative moment was performed, which used the participants' reports to make sense, logic and to highlight the responses, seeking understanding and aggregation. Following, the data encompassing the transcription of the material obtained through interviews, focus group, and rereading of the material were ordered. Then, the data started to be classified through the horizontal and comprehensive reading of the texts, allowing to capture the relevant structures and central ideas. In the cross-sectional reading, the data were separated into units of meaning, i.e., themes. In the classifying process, categories were identified to join similar parts, seeking to understand the connections among them and storing them in $\operatorname{code}^{(12)}$. In the final analysis, data were discussed in the light of the literature and the PNHOSP.

\section{RESULTS}

From the reading, organization, and subsequent classification of data, three categories emerged: recognition of the importance of quality indicators; use of quality indicators in the hospital environment; and contributions of quality indicators for the management of best practices in Health.

\section{Recognition of the importance of quality indicators}

The first category presented the participants' recognition about the quality indicators. In the interviews and focus group discussions, quality indicators were appointed as elements measured on a monthly basis, showing the outcomes of care work and enabling identifying whether the goals of care are being reached. Some statements show this understanding:

Indicators are values for us to measure, to know our results in that month. The outcome of our work is evaluated through indicators. (N2)

Indicators show the data we have worked in that month, our successes and mistakes. (N8)

They show if we are reaching the goal, as an institution, of this patient's care. (N3)

If we did not work with indicators, I do not know what would be the purpose of our work, we would not know our results. (FG1)

The quality indicators we work with, such as infection indexes, quantitative of falls, losses of probes, the incidence of skin lesion, show us how everyone reaches what is expected. (FG2)

Participants also mentioned that quality indicators are a tool for improving care and, in addition to assisting nurses in knowing the patients whom care is provided to, may help the clinical decision-making regarding best practices in health care, as reported below:

These are data I will collect from the work I developed, in which I will be able to analyze whether I need to improve in that respect, maintain, or modify. It is a tool that assists in improving health care, in decision-making. (FG1)

Indicators show us what we are doing, how we are practicing our care. (N10)

I believe quality indicators are important for measuring and assessing what is right and what is wrong in the units, even for us 
to make some decisions, primarily infection-related precaution measures. (N4)

One can see that statements provided in the interviews and focus groups converge about the recognition of the importance of quality indicators, which reinforces its concept as a management tool to asses the quality of care and, if necessary, modify it according to evidence, aimed at best practices in care.

\section{Use of quality indicators in the hospital environment}

This category addressed how nurses have been using quality indicators in the hospital environment. Most participants work with indicators in a retrospective manner because, at the end of each month, there is a critical analysis of results and a plan of action is devised with the nursing team for indicators that do not reach the goal proposed. It is worth mentioning that the monthly indicator analysis allows to promptly establish plans of action to remedy unreached goals, giving momentum to the process. This second category of analysis can be illustrated with the following statements:

We collect the data, analyze it, present it, and try to devise a plan of action in the attempt to correct such deficiencies. (N1)

We have a goal. When the goal is not reached, we need to review the process and try to discuss with the team why did that happen, and try to create some plan of action. (N6)

According to the indexes, we work with the collaborators, trying to improve these indicators, showing the need for what they are indicating, so that the care improves overall. (N3)

I use indicators in health care practice to know the epidemiological profile of the sector, analyzing infections, adverse events. At the end of the month I gather the team and show the data, so we draw plans of action to improve what was underwhelming. (FG6)

In exercising leadership, the nurse can transform the care and make it dynamic, unite the team around a common goal, and get better results. By analyzing their practice from quality indicators of health care, the leading nurse contributes to the clinical management and the administration of hospital costs, as exemplified in the statements below:

We used to have a great loss of probe, due to bad fixation. Then, we noticed that the fixation used to stand for three days before being replaced.... We started to look more to the patients and demand fixation replacements by the nursing team. (N12)

For example, we use the patient infection index, and whenever we present it we try to perform an action within the sector ... If the costs are high and over that expected, we perform actions in other sectors to try to fight it. (FG4)

By raising the awareness of the nursing staff on the importance of quality indicators for patient care, the nurse understands their role within the management of best practices in Health. Teams cannot work only because they are demanded to, but because they believe in the importance of indicators and recognize their benefits to the practice.

\section{Contributions of quality indicators for the management of best practices in Health}

Regarding quality indicators for the management of best practices in Health, nurses reported they assist in the work process, stimulating the critical thinking and favoring a better understanding of care, as well as promoting the prevention of future damages and mistakes in this practice.

I believe indicators are very important because they make us think about and understand the work process ... The indicator served for making us more than mere task-tacklers, for us to understand what we are doing and the outcomes of it. (N2)

At the moment I know my infection index increased that month, I am going to find the source of this and manage the infection control otherwise. Where did the failure occur: was it in the direct care to the patient? Was it in the preparation of any medication? Was it in some transport that such failure occurred? So the indicators help me manage this way, avoiding future damage or errors. (FG3)

Furthermore, they mentioned that indicators promote guidance to the care, as well as promote improvements in the management of best practices in Health since they characterize the patient profile and their needs.

I think indicators give us a direction for the care, we can see which patients are at aspiration hazard, infection risk, a risk offalling. (N5)

Through quality indicators, I could train my team regarding obstruction of enteral probes; we had a lot of losses, so we performed a training and could thus improve the results of the indicator and of the health care. (FG3)

The participants consider the management of best practices in Health as the planning and organization of care to the person, as well as the visualization of the patient in an individual manner.

This is about making a plan, seeing the patient as a whole, assessing what they need in terms of prevention and care of the framework they present, if it is clinical, surgical, in short, seeing them as a person who had s social life, who depends on our care, a patient who will go away from that place. (N11)

I believe each patient has a particularity. There are patients who need social assistance, such as the ones who have no family; others really need a technical assistance; we must identify the kind of care the patient requires. (FG4)

One can see the management of best practices in Health promotes individualized care planning, according to the patients and their needs.

\section{DISCUSSION}

Quality indicators are recognized as an indispensable tool for the management of best practices in the hospital environment. Values measured show the result of care and allow assessing whether care goals have been reached; they assist in the knowledge about patients cared for, in addition to signalizing improvements 
in care regarding the patient-centered care, helping the nurses' planning and decision-making for the evidence-based practice.

Findings of this study are in accordance with what is advocated by the PNHOSP, considering the hospital care model must meet a set of care devices that ensure access, care quality, and patient safety, striving for safe and resolutive interventions, avoiding unsafe and relating to health care ${ }^{(10)}$.

The participants' perception is close, still, to data from a Chinese study that shows quality indicators as the basis for management and monitoring of nursing care quality ${ }^{(13)}$. It is known that assessing care quality is essential - and, once the indicators are recognized as useful tools for measuring the nursing care and its quality, allowing the identification of failures in the work process, they are regarded as the first step for establishing excellence standards and continuous improvement of health care ${ }^{(14)}$.

In the interim, it is worth highlighting that the analysis of the urinary tract infection indicator, associated with the use of late bladder catheter, revealed the occurrence of care failures and, from this finding, preventive measures could be applied to decrease these occurrences ${ }^{(15)}$. These results agree with this study since the nurses also reported that quality indicators are tools for improvements; thus, their results cam promote changes in the daily nursing practices. The situation describe configures the evidence-based practice, in which decisions are taken from scientific evidence, where the resources available and the clinical competence play an active role in the decision-making process, meeting the patients' needs ${ }^{(16)}$.

A study on the incidence of pressure ulcers has shown that its analysis and monitoring may enable the identification of sites with greater occurrence within the institutions, risk patients, related factors and opportunity for improvements ${ }^{(17)}$. Quality indicators in the health care practice may assist in the clinical decision-making, as seen in the nurses' statements, due to allowing a broader view on the type of patient hospitalized and their health needs.

Care assessment through quality indicators is useful for diagnosis, defining the conformity index and determining goals, as well as the planning of activities ${ }^{(15)}$. A study on the results of care indicators before and after the quantitative adequacy of staff, identified improvements regarding fall, infection, urinary tract, and ulcers indicators ${ }^{(18)}$. Indicators must be a tool used to compare results and promote change since they depict evidence of health care results. However, the professionals' understanding on the use of quality indicators and their management is very important: without adherence to all stages of the process, there is a risk it only comes to fulfilling information on forms and accumulating records. Without further analysis and the elaboration of plans of action, as needed, the effort in data collection will have been worthless. Moreover, hospital managers must offer conditions for the team to move on the improvements from the indicators results because, without conditions of personnel, structure, and supplies, the professionals may perceive a scenario of barriers and not of improvement in the health care, which may lead to team demotivation.

In addition, in the perspective proposed by $\mathrm{PNHOSP}$, it is the responsibility of hospital institutions: the guarantee of access, equity and integrality in hospital care; the continuity of care through the articulation of the hospital with other points of attention of the health network; the model focused on patient care in a multi-professional and interdisciplinary way; humanized attention; technology management, quality of hospital care and patient safety; participation and social control; monitoring; and the evaluation of the services provided ${ }^{(10)}$. We emphasize that hospital institutions play an important role regarding health in the society and must constantly worry about the planning of hospital management so that its guidelines are reaffirmed and achieved; thus, the implementation of quality indicators can be a proposal for assessing the services provided to SUS patients.

Concerning the use of quality indicators in the health care practice, the study participants reported this has been a very common practice among the nurses of the institution, making it possible to know the epidemiological profile of the sector and guiding the elaboration of plans of action for indicators that have not reached the goals proposed. On the other hand, the statements do not address aspects regarding the effectiveness of action plans, not allowing one to deepen this discussion and, therefore, being a limitation of this study. It is suggested that the way the quality indicators are seen today is rethought, to involve the multidisciplinary team in the discussion of results, looking for the effectiveness of care provided by the whole health team and the support to evidence-based practice.

We complement this argument by pointing out that hospitals that provide health care within the SUS must have their mission and assistance profile defined according to the demographic and epidemiological portrait of the population and the design of regional $\mathrm{HCNs}$, bound to a reference population, with a defined territorial base, regulated access and service on referenced or spontaneous demand - in addition to ensure the resolutiveness of health care ${ }^{(10)}$. The delineation of the institution's epidemiological profiled based on its indicators, in addition to the construction of reference streams, culminate in a quality health care and in ensuring the continuity of integral care to the patient.

The study findings partially converge to another research ${ }^{(14)}$ conducted with nurses who work with indicators, in regards to their knowledge about it and the recognition that these are tools that make the improvement of health care practice possible. However, findings of this study differ from the study mentioned ${ }^{(14)}$ regarding the incorporation of all phases of management of indicators, such as data interpretation, analysis and plan of action; often the nurses do not know what to do with all these numbers. Yet, it should be noted that reaching quality in health services needs to be a collective attitude, not a policy isolated to few teams. For these reason, nurses require support from senior management to work with quality indicators, as well as opportunities to improve their knowledge in the institution.

Continuing education can be a strategy advocated in the PNHOSP: a program can be offered to health professionals and hospital teams, based on service learning, in which learning and teaching are incorporated to the routine of institutions and professionals ${ }^{(10)}$. It is noteworthy the group of quality indicators present in the institution under study, which may help professionals further in the use of quality management tools. We emphasize the importance of expanding the quality culture in health and nursing services, training nurses and other professionals to develop and analyze indicators and, furthermore, dynamically enabling the reflection on the care, aimed at health care excellence ${ }^{(2)}$. 
Evidence-based practice is a fundamental tool for patients' outcomes; hence, the nurse, when searching for reasoned improvements for their clinic, contributes with managerial results ${ }^{(19)}$. This concept agrees with the nurses' reports, as they report using indicators for knowing the epidemiological profile of the sector, analyzing infections, sentinel events, and cost management to, then, devise improvements with the team concerning the clinical management.

Clinical management, according to the PNHOSP, are assistance and managerial practices developed from the characterization of patients' profile, through the management of beds, co-responsibility of the team, $\mathrm{s}$ and assessment of health care indicators ${ }^{(10)}$.

Teamwork has also reflected positively on patient safety and the provision of effective care, in addition to favoring the decision-making and enabling an effective problem-solving ${ }^{(20)}$. The patient-centered model of attention, in a multi-professional and interdisciplinary manner, is part of the PNHOSP guidelines ${ }^{(10)}$. It is important to stress that indicators shall not be used by the team only because they are metrics recommended by the current models of health management; they must be used due to their daily importance for the qualified care to the patient.

Quality indicators are being widely used in the health field to measure, assess, and improved the quality of health care, a practice that is enhanced by the PNHOSP. The composition of the hospital care in the SUS needs to be organized from the needs of the population, to ensure assistance to the patients. The multi-professional team must be the nuclear structure of health services, being responsible for sharing information an decisions horizontally, establishing itself as a reference for patients ${ }^{(10)}$.

As seen in the statements, it is through quality indicators that nurses think and understand the work process and plan and organize the health care, as well as knowing the assistance profile of the patients they are providing care to, so that the care provided may generate beneficial and important impact on the final outcome of their health. The use of indicators can be a tool for the proactive management of nurses, and may reflect positively in the quality of care and in the implementation of best practices in health from the evidence-based practice.

The contribution of quality indicators for the management of nursing care is valued by nurses, being evidenced that $79.9 \%$ of these professionals consider that the greatest benefit of indicators is the identification of training needs in the nursing team; $73.4 \%$ consider that indicators help setting goals for improving the nursing care ${ }^{(4)}$. Looking at the data found in the indicators is part of the management of best practices in Health since the greater attention to them can provide care that avoid future damages to the patient, a perception shared by the nurses in this study. When questioned on the representativeness of the management of best practices in health care, the participants reported that it allows planning and organizing care, as well as favoring the individual attention to the patient. Thus, the recognition of quality indicators and their use within the hospital environment positively interfere on the management of best practices in Health and in the care provided.

\section{Study limitations}

A study limitation to be considered concerns the non generalizability of results because they are limited to the specific characteristics of a hospital context; therefore, other cases are needed for analysis. Another aspect to be considered is related to the option for investigating the theme with nurses already sensitized for the use of indicators as strategies for a qualified and safe care. The inclusion of participants without experience in the incorporation of indicators in the daily practice could reveal other categories of analysis. We believe this could be the focus of a future study, as well as the multidisciplinary perspective.

\section{Contributions to the fields of nursing, health, or public policy}

This research may contribute to the study institution since it leads to a reflection on the recognition, use, and contributions of quality indicators to hospital care. Furthermore, one can say the study enables the health team to rethink its way of working with quality indicators, with the purpose of a collective discussion with the multidisciplinary team. Regarding health care, the study showed to other institutions that are still starting this process the importance and impact on patient care when one works with these indicators.

Finally, we emphasize that results obtained in this study involve the nursing work, for recognizing the importance of indicators, as well as aspects that must be improved, aimed at increasing adherence to them in the hospital environment and, consequently, the management of best practices in Health.

\section{FINAL CONSIDERATIONS}

This study made it possible to analyze the recognition, use, and the contributions of quality indicators on nursing practices in the hospital environment. Given this context, we showed that quality indicators are recognized as tools for measuring the health care results, favoring the knowledge on patients met and revealing the scope of the objectives proposed, as well as assisting in the process of continuous improvement of health care and decision-making regarding care practices, such as best practices of health care.

Regarding their use, quality indicators have been approached by the nursing team of the hospital through discussions, and the construction of their critical analysis and plans of action is performed through work education. However, quality indicators are not yet analyzed with the other members of the multidisciplinary team. Also unmeasured is the effectiveness of action planta; i.e., how much the planning and the changes of conduct before indicators contributes to improved results. Furthermore, we must keep in mind that the PNHOSP, as a policy for strengthening and consolidating the SUS, defends the planning of strategy based on monitoring and assessment, which can be worked from quality indicators of health care. We emphasize the need for evidencebased practice and collective work with the multidisciplinary team for a more comprehensive, quality care, based on best practices in Health.

Concerning contributions in the use of quality indicators, the participants report they assist in understanding the work process, as well as provide guidance and improvement in the management of best practices in Health, mainly in the individual perspective of the patient-centered health care. 


\section{REFERENCES}

1. Januário GC, Lemos SMA, Friche AAL, Alves CRL. Quality indicators in a newborn hearing screening service. Braz J Otorhinolaryngol [Internet]. 2015 [cited 2017 Mar 16];81(3):255-63. Available from: http://www.scielo.br/pdf/bjorl/v81n3/pt_1808-8694-bjorl-81-03-00255.pdf

2. Gabriel CS, Melo MRAC, Rocha FLR, Bernardes A, Miguelaci T, Silva MLPS. Use of performance indicators in the nursing service of a public hospital. Rev Latino-Am Enfermagem [Internet]. 2011 [cited 2017 Mar 16];19(5). Available from: http://www.scielo.br/pdf/rlae/v19n5/pt_24.pdf

3. Van Dishoeck AM, Looman CWN, Steyerberg EW, Halfens RJG, Mackenbach JP. Performance indicators: the association between the quality of preventive care and the prevalence of hospital-acquired skin lesions in adult hospital patients. J Adv Nurs [Internet]. 2016 [cited 2017 Mar 16];72(11):2818-30. Available from: https://www.researchgate.net/publication/303951673_Performance_indicators_the_association_ between_the_quality_of_preventive_care_and_the_prevalence_of_hospital-acquired_skin_lesions_in_adult_hospital_patients

4. Van Dishoeck AM, Looman CWN, Van Der Wilder-Van LEC, Mackenbach JP, Steyerberg EW. Displaying random variation in comparing hospital performance. BMJ Qual Saf [Internet]. 2011 [cited 2017 Mar 16];20(8):651-7. Available from: https://www.researchgate.net/ publication/49749119_Displaying_random_variation_in_comparing_hospital_performance

5. Van Dishoeck AM, Lingsma HF, Mackenbach JP, Steyerberg EW. Random variation and rankability of hospitals using outcome indicators. BM Qual Saf [Internet]. 2011 [cited 2017 Mar 16];20(10):869-74. Available from: http://qualitysafety.bmj.com/content/20/10/869.long

6. Rossaneis MA, Gabriel CS, Haddad MCL, Melo MRAC, Bernardes A. Health care quality indicators: the opinion of nursing managers of teaching hospitals. Cogitare Enferm [Internet]. 2015 [cited 2017 Mar 16];20(4):798-804. Available from: http://revistas.ufpr.br/cogitare/ article/view/41734/26785

7. Cavalcante OS, Rossaneis MA, Haddad MCL, Gabriel CS. Healthcare quality indicators used in hospital nursing care management Rev Enferm UERJ [Internet]. 2015 [cited 2017 Mar 16];23(6):787-93. Available from: http://www.e-publicacoes.uerj.br/index.php/ enfermagemuerj/article/view/7052/16181

8. Oliveira RM, Leitão IMTA, Silva LMS, Figueiredo SV, Sampaio RL, Gondim MM. Strategies for promoting patient safety: from the identification of the risks to the evidence-based practices. Esc Anna Nery [Internet]. 2014 [cited 2017 Mar 16];18(1):122-9. Available from: http://www. scielo.br/pdf/ean/v18n1/1414-8145-ean-18-01-0122.pdf

9. Rabenschlag LA, Lima SBS, Eberhardt TD, Kessler M, Soares RSA, Vaghetti HH. Perception of nurses about the quality management in nursing care. Rev Enferm UFPE On line [Internet]. 2015 [cited 2017 Mar 16];9(11):9656-62. Available from: http://www.revista.ufpe.br/ revistaenfermagem/index.php/revista/article/view/7803/pdf_8786

10. Ministério da Saúde (BR). Ordinance no. 3,390, of December 30th, 2013. Diário Oficial da União [Internet]. 2013 Dec 30 [cited 2017 Mar 18]. Available from: http://bvsms.saude.gov.br/bvs/saudelegis/gm/2013/prt3390_30_12_2013.html Portuguese.

11. Atallah AN, Castro AA. Evidence-based Medicin: the link between good Science and best practices. Rev Imagem [Internet]. 1998 [cited 2018 Mai 2];20(1):V-IX. Available from: http://www.centrocochranedobrasil.com.br/apl/artigos/artigo_517.pdf Portuguese.

12. Minayo MCS. The challenge of knowledge: qualitative research in Health. 12th ed. São Paulo (SP): Hucitec; 2010.

13. Chen L, Huang LH, Xing MEU, Feng ZX, Shao LW, Zhang MY et al. Using the Delphi Method to develop nursing-sensitive quality indicators for the NICU. J Clin Nurs [Internet]. 2017 [cited 2017 Mar 16];26(3-4):502-13. Available from: http://onlinelibrary.wiley.com/doi/10.1111/ jocn.13474/abstract;jsessionid=8016326E6E90E59CF0697CB40E658E61.f03t03

14. Silveira TVL, Prado Jr PP, Siman AG, Amaro MOF. The importance of using quality indicators in nursing care. Rev Gaúcha Enferm [Internet]. 2015 [cited 2017 Mar 16];36(2):82-8. Available from: http://www.scielo.br/pdf/rgenf/v36n2/pt_1983-1447-rgenf-36-02-00082.pdf

15. Conterno LO, Lobo JA, Masson W. The excessive use of urinary catheters in patients hospitalized in university hospital wards. Rev Esc Enferm USP [Internet]. 2011 [cited 2017 Mar 16];45(5):1089-96. Available from: http://www.scielo.br/pdf/reeusp/v45n5/v45n5a09.pdf

16. Sackett DL, Straus SE, Richardson WS, Rosenberg W, Haynes RB, Livingstone C. Evidence based medicine: how to practice and teach EBM. London: Churchill Livingstone; 2000.

17. Santos CT, Oliveira MC, Pereira AGS, Suzuki LM, Lucena AF. Pressure ulcer care quality indicator: analysis of medical records and incident report. Rev Gaúcha Enferm [Internet]. 2013 [cited 2017 Mar 16];34(1):111-8. Available from: http://www.scielo.br/pdf/rgenf/v34n1/14.pdf

18. Quadros DV, Magalhães AMM, Mantovani VM, Rosa DS, Echer IC. Analysis of managerial and healthcare indicators after nursing personnel upsizing. Rev Bras Enferm [Internet]. 2016 [cited 2017 Mar 16];69(4):684-90. Available from: http://www.scielo.br/pdf/reben/v69n4/00347167-reben-69-04-0684.pdf

19. Lamont S, Brunero S, Lyons S, Foster K, Perry L. Collaboration amongst clinical nursing leadership teams: a mixed-methods sequential explanatory study. J Nurs Manag [Internet]. 2015 [cited 2017 Mar 16];23:1126-36. Available from: http://www.academia.edu/17320215/ Collaboration_amongst_clinical_nursing_leadership_teams_a_mixedmethods_sequential_explanatory_study

20. Valentine MA, Nembhard IM, Edmondson AC. Measuring teamwork in health care settings: a review of survey instruments. Med Care [Internet]. 2015 [cited 2017 Mar 16];53(4):16-30. Available from: https://rcrc.brandeis.edu/pdfs/Valentine\%20et\%20al\%202013.pdf 